\title{
JURNAL DISRUPSI BISNIS

\section{PENGARUH KOMPENSASI DAN DISIPLIN KERJA TERHADAP KINERJA KARYAWAN PADA PT POS INDONESIA DC CIPUTAT}

\author{
Angga Pratama \\ Fakultas Ekonomi Universitas Pamulang \\ dosen02155@unpam.ac.id
}

\begin{abstract}
ABSTRAK
Tujuan penelitian ini adalah untuk mengetahui pengaruh kompensasi dan disiplin kerja terhadap kinerja karyawan pada PT Pos Indonesia DC Ciputat baik secara parsial maupun secara simultan. Metode yang digunakan adalah metode deskriptif kuantitatif dengan populasi dalam penelitian ini adalah seluruh karyawan di dalam kantor sebanyak 50 orang. Metode penarikan sampel menggunakan teknik sampel jenuh, sehingga seluruh populasi dijadikan sampel. Metode analisis dalam pengelolaan data adalah dengan uji validitas, uji reliabilitas, uji asumsi klasik, uji regresi linier berganda, uji koefisien korelasi, uji koefisien determinasi, dan uji hipotesis. Hasil uji validitas untuk kompensasi, disiplin kerja dan kinerja karyawan diperoleh nilai $r_{\text {hitung }}$ lebih besar dari nilai $r_{\text {tabel }}$. Nilai $r_{\text {tabel }}$ diperoleh dengan rumus $\mathrm{df}=\mathrm{n}-\mathrm{k}(50-3=47)$ dengan taraf signifikan 5\%, maka dapat disimpulkan semua variabel dalam penelitian ini adalah valid. Hasil uji reliabilitas terhadap variabel kompensasi, disiplin kerja dan kinerja karyawan diperoleh nilai $\mathrm{r}_{\text {hitung }}>$ Cronbach Alpa $(0,60)$, maka dapat disimpulkan semua variabel yang digunakan dalam penelitian ini adalah reliabel. Berdasarkan hasil dari analisis regresi linier berganda yaitu $Y=13,570+0,553 \mathrm{X}_{1}+0,178 \mathrm{X}_{2}$. Hasil uji $t$ pertama diperoleh $t_{\text {hitung }}$ sebesar 7,045 $>\mathrm{t}_{\text {tabel }} 1,67$ dan nilai signifikasi $(0,000<$ 0,05) maka dapat disimpulkan bahwa kompensasi secara parsial berpengaruh positif dan signifikan terhadap kinerja karyawan pada PT Pos Indonesia DC Ciputat. Nilai t kedua diperoleh $t_{\text {hitung }}$ sebesar 6,352 $>\mathrm{t}_{\text {tabel }} 1,67$ dan nilai signifikasi $(0,000<0,05)$ maka dapat disimpulkan bahwa disiplin kerja secara parsial berpengaruh positif dan signifikan terhadap kinerja karyawan. Hasil uji f secara simultan diperoleh $f_{\text {hitung }}$ sebesar 24,883 $>\mathrm{f}_{\text {tabel }} 2,80$ dengan nilai signifikasi sebesar $(0,000<0,05)$ maka dapat disimpulkan bahwa kompensasi dan disiplin kerja secara simultan berpengaruh positif dan signifikan terhadap kinerja karyawan. Hasil uji koefisien korelasi secara simultan sebesar 0,713 dan 0,676. Nilai ini menunjukkan bahwa pengaruh antara variabel kompensasi dan disiplin kerja terhadap kinerja karyawan memiliki tingkat kekuatan hubungan yang kuat. Hasil koefisien determinasi yaitu (R Square) $0,514=51,4 \%$ terdapat pengaruh antara kompensasi dan disiplin kerja terhadap kinerja karyawan PT Pos Indonesia DC Ciputat.
\end{abstract}

Kata kunci: Kompensasi, Disiplin Kerja dan Kinerja Karyawan 


\begin{abstract}
The purpose of this study was to determine the effect of compensation and work discipline on employee performance at PT Pos Indonesia DC Ciputat both partially and simultaneously.The method used is a quantitative descriptive method with the population in this study are all employees in the office of 50 people. The sampling method uses the saturated sample technique, so that the entire population is sampled. The analytical method in data management is the validity test, reliability test, classic assumption test, multiple linear regression test, correlation coefficient test, coefficient of determination test, and hypothesis testing.The validity test results for compensation, work discipline and employee performance obtained rcount value greater than the rtable value. The rtable value obtained by the formula $d f=n-k(50-3=47)$ with a significance level of $5 \%$, it can be concluded that all variables in this study are valid. The reliability test results on the compensation variable, work discipline and employee performance obtained rcount> Cronbach Alpa (0.60), it can be concluded that all variables used in this study are reliable. Based on the results of multiple linear regression analysis, $Y=13.570+0.553 X 1$ $+0.178 X 2$. The first $t$ test results obtained tcount of 7.045> $t$ table 1.67 and the significance value $(0.000<0.05)$, it can be concluded that partial compensation has a positive and significant effect on employee performance at PT Pos Indonesia DC Ciputat. The second $t$ value is obtained tcount of 6.352> $t$ table 1.67 and the significance value $(0.000<0.05)$, it can be concluded that work discipline partially has a positive and significant effect on employee performance. The $f$ test results simultaneously obtained fcount of 24.883> ftabel 2.80 with a significance value of $(0.000<0.05)$, it can be concluded that compensation and work discipline simultaneously have a positive and significant effect on employee performance. The results of the correlation coefficient test simultaneously were 0.713 and 0.676. This value indicates that the effect between compensation variables and work discipline on employee performance has a strong level of relationship strength. The results of the coefficient of determination are ( $R$ Square) $0.514=51.4 \%$ there is an influence between compensation and work discipline on the performance of employees of PT Pos Indonesia DC Ciputat.
\end{abstract}

Keywords: Compensation, Work Discipline and Employee Performance

\title{
PENDAHULUAN
}

\section{A. Latar Belakang}

Manajemen sumber daya manusia sangat penting dan menjadi fokus banyak organisasi dalam mencapai tujuan tertentu. Berhasil atau tidaknya suatu organisasi dalam mencapai tujuannya tergantung oleh keberhasilan daripada individu karyawan perusahaan itu sendri dalam menjalankan tugas dan tanggung jawab mereka. Dalam sebuah organisasi setiap individu didalamnya selalu berusaha mewujudkan tujuan bersama dengan memanfaatkan seluruh sumber daya yang ada.

Menurut Hasibuan (2017:118) Kompensasi adalah semua pendapatan yang berbentuk uang, barang langsung atau tidak langsung yang diterima karyawan sebagai imbalan atas jasa yang diberikan kepada perusahaan. Jika penerimaan kompensasi sudah sesuai tetapi kinerja karyawan belum maksimal, maka perusahaan harus menetapkan peraturan kerja yang tetap sehingga tujuan perusahaan dapat tercapai.

Menurut Sutrisno (2011:94) bahwa disiplin kerja adalah sikap kesediaan dan kerelaan seseorang mematuhi dan mentaati norma-norma peraturan yang berlaku di sekitarnya. Adapun disiplin pada hakikatnya mencerminkan besarnya tanggung jawab 
seseorang terhadap tugas yang diberikan kepadanya. Disiplin kerja diartikan jika karyawan selalu datang dan pulang tepat pada waktunya, mengerjakan semua pekerjaannya dengan baik dan tepat waktu, melaksanakan perintah atasan. Tanpa disiplin karyawan sangat sulit bagi perusahaan mencapai hasil yang optimal.

Menurut Mangkunegara (2017:67) bahwa kinerja adalah hasil kerja secara kualitas dan kuantitas yang dapat dicapai oleh seseorang pegawai dalam melaksanakan tugasnya sesuai dengan tanggung jawab yang di berikan kepadanya.

Berdasarkan uraian diatas peneliti merasa tertarik untuk melakukan penelitian dengan judul "Pengaruh Kompensasi Dan Disiplin Kerja Terhadap Kinerja Karyawan Pada PT. Pos Indonesia Dc Ciputat".

\section{B. Perumusan Masalah}

Berdasarkan latar belakang yang telah diuraikan di atas maka penulis merumuskan masalah sebagai berikut:

1. Bagaimana pengaruh kompensasi terhadap kinerja karyawan secara parsial pada PT Pos Indonesia Dc Ciputat?

2. Bagaimana pengaruh disiplin kerja terhadap kinerja karyawan secara parsial pada PT Pos Indonesia Dc Ciputat?

3. Seberapa besar pengaruh kompensasi dan disiplin kerja terhadap kinerja karyawan secara simultan pada PT Pos Indonesia DC Ciputat?

\section{Pembatasan Masalah}

Mengingat begitu luasnya ruang lingkup dalam penelitian ini, maka penulis membatasi permasalahan pada variabel Kompensasi, disiplin dan kinerja karyawan. Objek penelitian pada PT. Pos Indonesia Dc Ciputat yang berlokasi di Jalan R.E. Martadinata No. 17, Pondok Cabe Udik, Pamulang serta wktu penelitian kurang lebih selama 4 bulan.

\section{Tujuan Penelitian}

Perumusan masalah yang penulis tetapkan akan di uraikan dan menjadi rumusan masalah pada penelitian sebagai berikut:

1. Bagaimana pengaruh kompensasi terhadap kinerja karyawan secara parsial pada PT Pos Indonesia Dc Ciputat?

2. Bagaimana pengaruh disiplin kerja terhadap kinerja karyawan secara parsial pada PT Pos Indonesia Dc Ciputat?

3. Seberapa besar pengaruh kompensasi dan disiplin kerja terhadap kinerja karyawan secara simultan pada PT Pos Indonesia DC Ciputat?

\section{E. Manfaat Penelitian}

Dari hasil penelitian ini diharapkan dapat memberi manfaat bagi semua pihak, diantaranya:

1. Manfaat Teoritis

a. Bagi Penulis

Untuk menambah wawasan, pengetahuan dan perbandingan dalam melakukan penelitian pada bidang yang sama dan penelitian ini merupakan kesempatan yang baik bagi penulis untuk dapat menerapkan ilmu yang telah diperoleh selama perkuliahanManfaat Praktis

b. Bagi Akademis

Memberikan manfaat teoritis dan tambahan kontribusi informasi sebagai referensi untuk penelitian lanjutan di bidang sumber daya manusia

2. Manfaat Praktis 
Diharapkan hasil penelitian ini dapat memberi saran dan masukan yang bermanfaat bagi perusahaan dalam menjaga hak kompensasi dan sikap disiplin untuk mempertahankan kinerja karyawan

\section{TINJAUAN PUSTAKA}

\section{A. Kompensasi}

Menurut penelitian Linda Suprihatin (2019:5) Kompensasi merupakan balas jasa yang diberikan oleh organisasi/unit kerja kepada pegawai, yang dapat bersifat finansial maupun non finansial, pada periode yang tetap. Sistem kompensasi yang baik akan mampu memberikan kepuasan bagi pegawai dan memungkinkan unit kerja organisasi memperoleh, mempekerjakan, dan mempertahankan pegawai.

Menurut Hasibuan (2017:118) Kompensasi adalah semua pendapatan yang berbentuk uang, barang langsung atau tidak langsung yang diterima karyawan sebagai imbalan atas jasa yang diberikan kepada perusahaan.

\section{B. Disiplin Kerja}

Menurut Hasibuan (2017:193) disiplin kerja adalah kesadaran atau kesediaan seseorang mentaati semua peraturan perusahaan dan norma-norma social yang berlaku. Menurut BA Husain (2018:6) Disiplin kerja merupakan suatu bentuk upaya pegawai yangberusaha memperbaiki dan membentuk pengetahuan ,sikap dan perilaku karyawan sehinggaperilaku karyawan tersebut secara sukarela berusaha bekerja secara koperatif dengan para karyawanlain serta meningkatkan prestasi kerja

\section{Kinerja}

Menurut Mangkunegara (2017:67) menyatakan bahwa kinerja adalah hasil kerja secara kualitas dan kuantitas yang dapat dicapai oleh seseorang pegawai dalam melaksanakan tugasnya dengan tanggung jawab yang diberikan kepadanya. Menurut Sedarmayanti (2011:260) menyatakan bahwa kinerja merupakan terjemahan dari performance yang berarti hasil kerja seorang pekerja. Sebuah proses manajemen atau suatu organisasisecara keseluruhan, dimana hasil kerja tersebut harus dapat ditunjukkan buktinya secra konkrit dan dapat diukur (dibandingkan dengan standar yang telah ditentukan). Menurut Triyono dalam Angga Pratama untuk dapat mewujudkan tujuan tersebut banyak faktor yang mempengaruhinya diantaranya faktor internal organisasi seperti komitmen organisasi, kompensasi, kepuasan karyawan, dimana komponen komponen tersebut mempunyai peranan dalam menentukan kinerja yang dihasilkan karyawan.

\section{Kerangka Pemikiran}

Berdasarkan teori diatas kerangka berpikir dalam penelitian ini dapat digambarkan sebagai berikut:

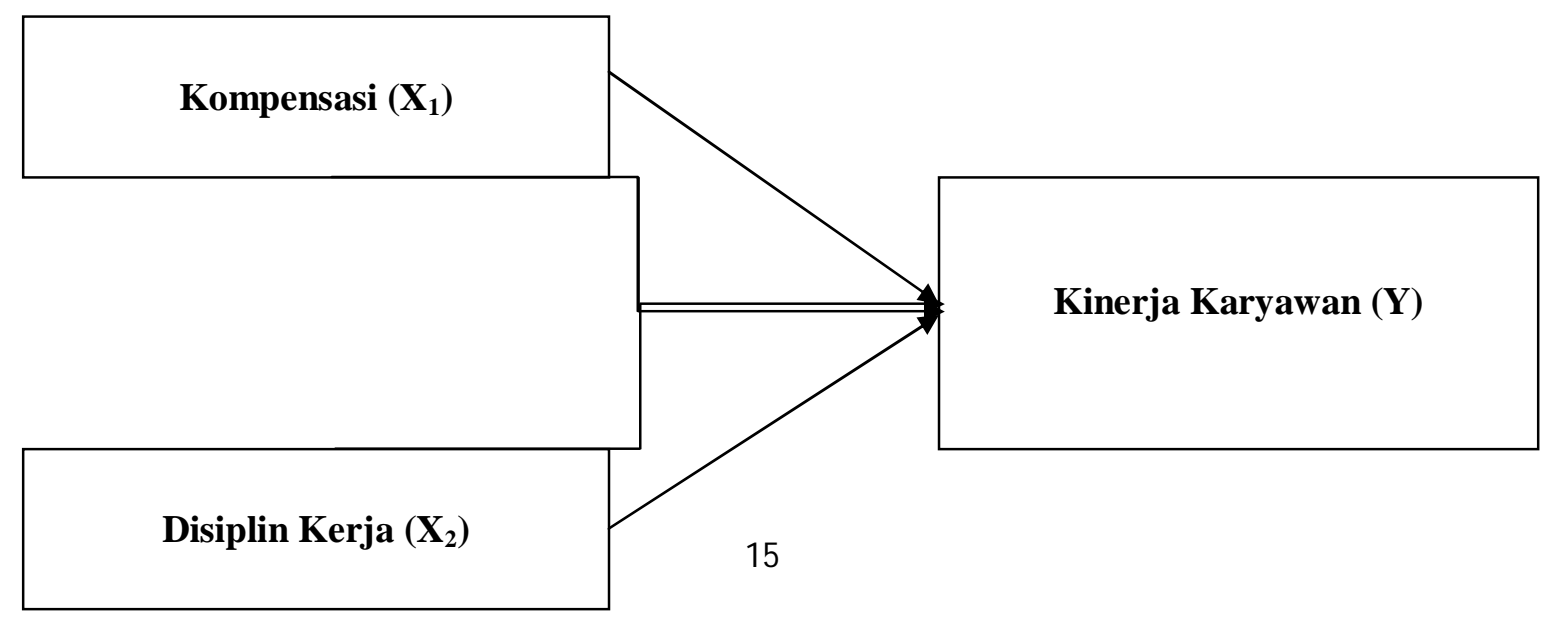




\section{Gambar \\ Kerangka Berfikir}

\section{E. Hipotesis Penelitian}

Hipotesis penelitian ini untuk menguji ada tidaknya pengaruh antara variabel independen $(\mathrm{X})$ yaitu kompensasi $\left(\mathrm{X}_{1}\right)$, disiplin kerja $\left(\mathrm{X}_{2}\right)$ terhadap kinerja karaywan sebagai variabel dependen $(\mathrm{Y})$. Adapun yang menjadi hipotesis nol $\left(H_{o}\right)$ dan hipotesis alternatif $\left(H_{\mathrm{a}}\right)$ dalam penelitian ini adalah sebagai berikut:

1. Kompensasi terhadap Kinerja Karyawan

$\mathrm{H}_{\mathrm{o} 1}: \beta_{1} \neq 0$, "tidak terdapat pengaruh yang signifikan dari kompensasi terhadap kinerja karyawan"

$\mathrm{Ha}_{1}: \beta_{1}=0$, "terdapat pengaruh yang signifikan dari kompensasi terhadap kinerja karyawan".

2. Disiplin Kerja terhadap Kinerja Karyawan

$\mathrm{H}_{\mathrm{o} 2}: \beta_{1} \neq 0$, "tidak terdapat pengaruh yang signifikan dari disiplin kerja terhadap kinerja karyawan"

$\mathrm{Ha}_{2}: \beta_{1}=0$, "terdapat pengaruh yang signifikan dari disiplin kerja terhadap kinerja karyawan".

3. Kompensasi dan Disiplin Kerja terhadap Kinerja Karyawan

$\mathrm{H}_{03}: \beta_{3} \neq 0$, "tidak terdapat pengaruh yang signifikan dari kompensasi dan disiplin kerja terhadap kinerja karyawan"

$\mathrm{Ha}_{3}: \beta_{3}=0$, "terdapat pengaruh yang signifikan dari kompensasi dan disiplin kerja terhadap kinerja karyawan".

\section{METODOLOGI PENELITIAN}

\section{A. Ruang Lingkup Penelitian}

Penulis menjalankan penelitian ini di PT. Pos Indonesia DC Ciputat yang beralamat di Jalan R.E. Martadinata No. 17, Pondok Cabe Udik, Pamulang, Pamulang Timur. Waktu penelitian dilaksanakan terhitung sejak Agustus 2019 sampai dengan November 2019. Dalam penelitian ini penulis menggunakan metode kuantitatif.

\section{B. Metode Populasi dan Sampel}

Adapun dalam penelitian ini yang menjadi populasi adalah semua karyawan operasional PT. Pos Indonesia sebanyak 50 orang berdasarkan data bulan Januari 2018. Pengambilan sampel ini adalah dengan menggunakan metode sampling jenuh. Oleh karena itu sampel dalam penelitian ini berjumlah 50 orang.

\section{Metode Pengumpulan Data}

Data yang digunakan dalam penelitian ini adalah data primer dan sekunder. Data Primer dalam penelitian adalah PT Pos Indonesia dimana penulis mendapatkan data karyawan, lama bekerja dan pendidikan terakhir karyawan. Data primer tersebut diperoleh dengan observasi dan kuesioner. Data sekunder dalam penelitian ini merupakan sumber data yang digali dari jurnal, artikel atau buku-buku ilmiah yng ada hubungannya dalam penelitian ini dan dokumen terkait yang diperlukan. Teknik pengumpulan data sekunder 
dilakukan dengan cara telaah dokumen yaitu mengumpulkan informasi dari data yang telah diolah seperti penilaian kinerja karyawan, sejarah perusahaan, struktur organisasi dan absensi karyawan.

\section{Teknik Pengumpulan Data}

Metode yang digunakan dalam penelitian ini adalah:

\section{Uji Validitas dan Reliabilitas}

\section{a. Uji Validitas}

Menurut Ghozali (2016:52) uji validitas adalah suatu alat yang digunakan untuk mengukur valid atau tidaknya suatu kuesioner instrument yang valid mempunyai validitas tinggi sebaliknya instrument yang kurang valid mempunyai validitas yang rendah. Dalam pengambilan keputusan uji validitas:

1) Jika $r$ hitung $>r$ tabel maka variabel valid. Taraf signifikan $5 \%$.

2) Jika $r$ hitung $<r$ tabel maka variabel tidak valid. Taraf signifikan $5 \%$.

\section{b. Uji Reliabilitas}

Reliabilitas adalah indeks yang menunjukkan sejauh mana alat pengukur dapat dipercaya atau diandalkan. Dasar pengambilan keputusan ialah sebagai berikut:

1) Jika Cronbach Alpha > 0.6 dinyatakan reliable.

2) Jika Cronbach Alpha < 0.6 dinyatakan tidak reliable

\section{Uji Asumsi Klasik}

\section{a. Uji Normalitas Data}

Uji normalitas bertujuan untuk menguji apakah dalam model regresi memiliki distribusi normal. Data yang baik dan layak dalam penelitian adalah yang memiliki distribusi normal.

\section{b. Uji heteroskedasitas}

Uji heteroskedasitas bertujuan menguji apakah dalam model regresi terjadi ketidaksamaan dari residual satu pengantaran ke pengantaran yang lain.

\section{c. Uji autokorelasi}

Uji autokorelasi bertujuan untuk menguji apakah dalam model regresi ada korelasi antara kesalahan pengganggu pada periode $=\mathrm{t}$ dengan kesalahan pengganggu pada periode t-1 (sebelumnya).

\section{Uji Hipotesis Penelitian}

\section{a. Uji t}

Uji statistik $\mathrm{t}$ pada dasarnya menunjukkan seberapa jauh pengaruh satu variabel independen secara individual dalam menerangkan variabel dependen. Jika nilai $t_{\text {hitung }}$ lebih besar dari $t_{\text {tabel }}$ dan $p$ value lebih kecil dari 0,05 maka Ho ditolak dan Ha diterima sebaliknya jika $t_{\text {hitung }}$ lebih kecil dari $t_{\text {tabel }}$ dan $p$ value lebih besar dari 0,05 maka Ho diterima dan Ha ditolak

\section{b. Uji F}

Pengujian hipotesis secara simultan dimaksudkan untuk mengetahui pengaruh Kompensasi (X1) dan Disiplin Kerja (X2) secara simultan terhadap Kinerja karyawan (Y) dapat dilakukan dengan uji statistik F (uji simultan). Signifikan dalam penelitian ini digunakan 5\% $(0,05)$ dengan membandingkan fhitung dengan ftabel dengan kriteria sebagai berikut:

1) Jika fhitung < ftabel, maka $\mathrm{H} 0$ diterima fan $\mathrm{H} 1$ ditolak.

2) Jika fhitung > ftabel, maka H0 ditolak dan H1 diterima 


\section{Koefisien Regrei Linier Berganda}

Analisis regresi linier berganda digunakan untuk meramalkan bagaimana keadaan naik turunnya variabel terikat, bila dua atau lebih variabel bebas sebagai faktor prediktor dimanipulasi dinaik turunkan nilainya.

\section{Koefisien Determinasi}

Untuk mengetahui berapa besarnya kontribusi kompensasi dan disiplin terhadap kinerja karyawan dapat dihitung dengan suatu besaran yang disebut koefisien determinasi yang biasanya dinyatakan dalam persentase $(\%)$ dan dinyatakan dengan $\mathrm{r} 2$.

\section{HASIL DAN PEMBAHASAN}

\section{A. Uji Instrumen Penelitian}

\section{Hasil Uji Validitas}

Teknik pengujian dengan membandingkan $r_{\text {hitung }}$ dengan $r_{\text {tabel }}$ Apabila $r_{\text {hitung. }}>$ $\mathrm{r}_{\text {tabel, }}$ maka pernyataan tersebut dinyatakan tidak valid.

\begin{tabular}{|c|c|c|c|}
\hline Pernyataan & rhitung & rtabel & Keterangan \\
\hline Pernyataan 1 & 0,367 & 0,281 & Valid \\
\hline Pernyataan 2 & 0,513 & 0,281 & Valid \\
\hline Pernyataan 3 & 0,368 & 0,281 & Valid \\
\hline Pernyataan 4 & 0,636 & 0,281 & Valid \\
\hline Pernyataan 5 & 0,762 & 0,281 & Valid \\
\hline Pernyataan 6 & 0,514 & 0,281 & Valid \\
\hline Pernyataan 7 & 0,575 & 0,281 & Valid \\
\hline Pernyataan 8 & 0,534 & 0,281 & Valid \\
\hline Pernyataan 9 & 0,322 & 0,281 & Valid \\
\hline Pernyataan 10 & 0,700 & 0,281 & Valid \\
\hline
\end{tabular}

Berdasarkan tabel di atas dapat diketahui bahwa semua item pernyataan pada variabel kompensasi (X1) setelah dilakukan pengujian menggunakan bantuan Program SPSS diperoleh nilai rhitung lebih besar dari nilai rtabel. Nilai rtabel diperoleh dengan rumus $\mathrm{df}=\mathrm{n}-\mathrm{k}(50-3=47)$ dengan taraf sig $5 \%$, maka diperoleh nilai rtabel sebesar 0,281. Jadi dapat disimpulkan bahwa semua item pernyataan yang digunakan dalam penelitian ini adalah valid.

\begin{tabular}{|c|c|c|c|}
\hline Pernyataan & rhitung & rtabel & Keterangan \\
\hline Pernyataan 1 & 0,447 & 0,281 & Valid \\
\hline Pernyataan 2 & 0,472 & 0,281 & Valid \\
\hline Pernyataan 3 & 0,703 & 0,281 & Valid \\
\hline Pernyataan 4 & 0,419 & 0,281 & Valid \\
\hline Pernyataan 5 & 0,698 & 0,281 & Valid \\
\hline Pernyataan 6 & 0,663 & 0,281 & Valid \\
\hline Pernyataan 7 & 0,468 & 0,281 & Valid \\
\hline Pernyataan 8 & 0,719 & 0,281 & Valid \\
\hline Pernyataan 9 & 0,293 & 0,281 & Valid \\
\hline
\end{tabular}

Berdasarkan tabel di atas dapat diketahui bahwa semua item pernyataan pada variabel disiplin kerja (X2) setelah dilakukan pengujian menggunakan bantuan Program SPSS diperoleh nilai $r_{\text {hitung }}$ lebih besar dari nilai rtabel. Nilai $r_{\text {tabel }}$ diperoleh 
dengan rumus $\mathrm{df}=\mathrm{n}-\mathrm{k}(50-3=47)$ dengan taraf sig $5 \%$, maka diperoleh nilai $\mathrm{r}_{\text {tabel }}$ sebesar 0,281 . Jadi dapat disimpulkan bahwa semua item pernyataan yang digunakan dalam penelitian ini adalah valid.

\begin{tabular}{|c|c|c|c|}
\hline Pernyataan & rhitung & rtabel & Keterangan \\
\hline Pernyataan 1 & 0,314 & 0,281 & Valid \\
\hline Pernyataan 2 & 0,536 & 0,281 & Valid \\
\hline Pernyataan 3 & 0,402 & 0,281 & Valid \\
\hline Pernyataan 4 & 0,395 & 0,281 & Valid \\
\hline Pernyataan 5 & 0,427 & 0,281 & Valid \\
\hline Pernyataan 6 & 0,550 & 0,281 & Valid \\
\hline Pernyataan 7 & 0,599 & 0,281 & Valid \\
\hline Pernyataan 8 & 0,442 & 0,281 & Valid \\
\hline Pernyataan 9 & 0,643 & 0,281 & Valid \\
\hline Pernyataan 10 & 0,359 & 0,281 & Valid \\
\hline
\end{tabular}

Berdasarkan tabel di atas dapat diketahui bahwa semua item pernyataan pada variabel kinerja (Y) setelah dilakukan pengujian menggunakan bantuan Program SPSS diperoleh nilai $r_{\text {hitung }}$ lebih besar dari nilai rtabel. Nilai $r_{\text {tabel }}$ diperoleh dengan rumus $\mathrm{df}=\mathrm{n}-\mathrm{k}(50-3=47)$ dengan taraf sig $5 \%$, maka diperoleh nilai $\mathrm{r}_{\text {tabel }}$ sebesar 0,281 . Jadi dapat disimpulkan bahwa semua item pernyataan yang digunakan dalam penelitian ini adalah valid.

\section{Hasil Uji Reliabilitas}

\begin{tabular}{|l|c|c|c|}
\hline \multicolumn{1}{|c|}{ Variabel } & $\begin{array}{c}\text { Cronbach } \\
\text { Alpha }\end{array}$ & $\mathrm{r}_{\text {hitung }}$ & Keterangan \\
\hline Kompensasi & 0,60 & 0,724 & Reliabel \\
\hline Disiplin Kerja & 0,60 & 0,725 & Reliabel \\
\hline Kinerja & 0,60 & 0,700 & Reliabel \\
\hline
\end{tabular}

Berdasarkan tabel di atas pengujian reliabilitas terhadap variabel kompensasi, disiplin kerja dan kinerja karyawan dapat diketahui bahwa nilai $\mathbf{r}_{\text {hitung }}$ semua variabel adalah diatas 0,60. Maka dapat disimpulkan semua variabel yang digunakan dalam penelitian ini adalah reliabel.

\section{Uji Asumsi Klasik}

\section{a. Hasil Uji Normalitas Data \\ 1) Hasil Uji Normalitas}




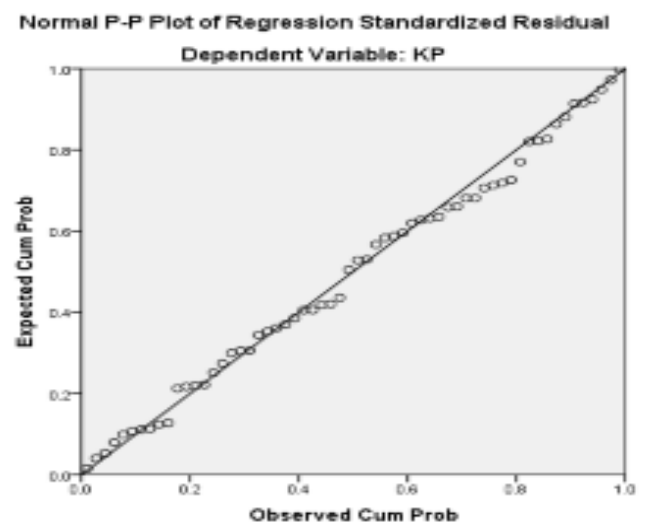

Melihat grafik normal probability plot di atas terlihat titik-titik menyebar disekitar garis diagonal dan penyebarannya mengikuti arah garis diagonal. Berdasarkan penjelasan tersebut maka pengaruh Kompensasi (X1), dan Disiplin Kerja (X2) terhadap Kinerja Karyawan (Y) memiliki data yang normal artinya sampel yang diambil dalam penelitian ini dapat mendeteksi karakteristik populasi yang hendak diestimasi.

\section{2) Uji Heteroskedastisitas}

\begin{tabular}{|c|c|c|c|c|c|}
\hline \multicolumn{6}{|c|}{ Coefficients $^{a}$} \\
\hline \multirow[b]{2}{*}{ Model } & \multicolumn{2}{|c|}{$\begin{array}{c}\text { Unstandardized } \\
\text { Coefficients }\end{array}$} & \multirow{2}{*}{$\begin{array}{c}\text { Standardized } \\
\text { Coefficients } \\
\text { Beta }\end{array}$} & \multirow[b]{2}{*}{$\mathrm{T}$} & \multirow[b]{2}{*}{ Sig. } \\
\hline & B & Std. Error & & & \\
\hline $\begin{array}{c}1 \text { (Consta } \\
\mathrm{nt})\end{array}$ & 4.127 & 2.311 & & 1.786 & .081 \\
\hline $\mathrm{X} 1$ & -.082 & .128 & -.212 & -.639 & .526 \\
\hline $\mathrm{X} 2$ & .029 & .135 & .071 & .214 & .832 \\
\hline
\end{tabular}

a. Dependent Variable: Abs_ut

Berdasarkan output diatas diketahui bahwa nilai signifikan variabel Kompensasi (X1) sebesar 0,526 lebih besar dari 0,05 artinya tidak terjadi heteroskedastisitas pada variabel Kompensasi (X1). Sementara itu, diketahui nilai signifikan variabel Disiplin (X2) yaitu 0,832 lebih besar dari 0,05 artinya tidak terjadi heteroskedastisitas pada variabel Disiplin Kerja (X2).

\section{3) Uji Autokorelasi}

\begin{tabular}{|l|c|c|c|}
\multicolumn{4}{c|}{ Model Summary } \\
\hline \multirow{4}{*}{ Model } & $\begin{array}{c}\text { Adjusted R } \\
\text { Square }\end{array}$ & $\begin{array}{c}\text { Std. Error of the } \\
\text { Estimate }\end{array}$ & \\
\hline
\end{tabular}




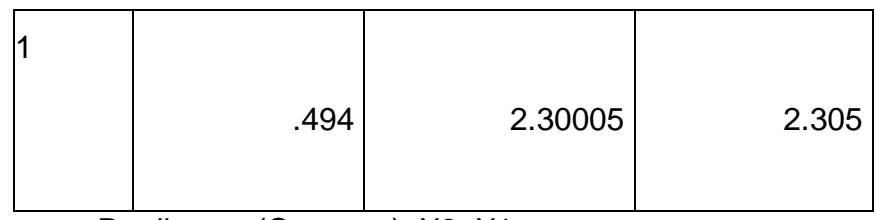

a. Predictors: (Constant), X2, X1

Berdasarkan uji Run Test pada tabel di atas menunjukkan bahwa nilai Durbin-Watson adalah sebesar 2,305. Nilai tersebut terletak antara 1,55 - 2,46. Jadi dapat disimpulkan bahwa data yang digunakan dalam penelitian ini tidak terjadi masalah autokorelasi.

\section{Analisis Uji t (Uji Parsial)}

\section{a. Uji Parsial X1 terhadap Y}

Pengujian hipotesis secara parsial dimaksudkan untuk mengetahui ada atau tidaknya pengaruh variabel bebas secara parsial terhadap variabel terikat. Hasil hipotesis dalam pengujian ini adalah sebagai berikut:

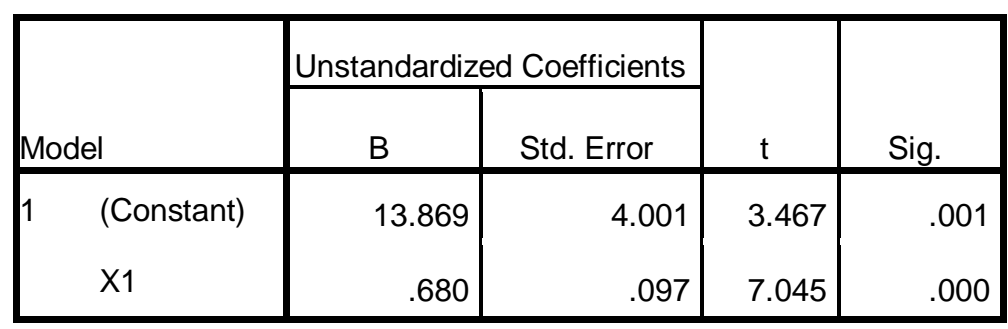

Berdasarkan tabel di atas diperoleh nilai thitung sebesar 7,045 dengan nilai signifikasi 0,000 dan ttabel 1,67. Nilai ttabel didapatkan dengan rumus $\mathrm{df}=\mathrm{n}-\mathrm{k}(50$ $3=47)$ sehingga dieproleh nilai 1,67. Karena thitung $>$ ttabel $(7,045>1,67)$ dan signifikansi $<0,05(0,000<0,05)$ maka dapat disimpulkan bahwa kompensasi secara parsial berpengaruh positif dan signifikan terhadap kinerja karyawan pada PT Pos Indonesia DC Ciputat.

\section{b. Uji F}

Pengujian hipotesis secara simultan bertujuan untuk mengukur besarnya pengaruh variabel bebas secara bersama-sama terhadap variabel terikatnya. Hasil hipotesis yang dalam pengujian ini adalah:

\begin{tabular}{|rl|r|r|r|r|}
\hline Model & & df & Mean Square & F & Sig. \\
\hline 1 & Regression & 2 & 131.639 & 24.883 & $.000^{\mathrm{b}}$ \\
& Residual & 47 & 5.290 & & \\
Total & 49 & & & \\
\hline
\end{tabular}

a. Dependent Variable: $Y$

b. Predictors: (Constant), X2, X1 
Berdasarkan tabel diatas diketahui nilai fhitung sebesar 24,883 dan nilai signifikansi sebesar 0,000. Nilai ftabel pada tingkat kepercayaan 5\% dengan df1 $=2$ dan df2 $=48$, maka didapatkan ftabel $=2,80$. Karena fhitung $>$ ftabel $(24,883>$ $2,80)$ dan nilai signifikan $<0,05(0,000<0,05)$ maka dapat disimpulkan bahwa variabel kompensasi dan disiplin kerja berpengaruh positif dan siginifikan terhadap kinerja karyawan pada PT Pos Indonesia DC Ciputat.

\section{Hasil Analisis Koefisien Regresi Linier Berganda}

\begin{tabular}{|c|c|c|c|}
\hline \multirow[b]{2}{*}{ Model } & \multicolumn{2}{|c|}{ Unstandardized Coefficients } & $\begin{array}{l}\text { Standardized } \\
\text { Coefficients }\end{array}$ \\
\hline & B & Std. Error & Beta \\
\hline (Constant) & 13.570 & 4.038 & \\
\hline $\mathrm{X} 1$ & .528 & .223 & .553 \\
\hline $\mathrm{X} 2$ & .179 & .236 & .178 \\
\hline
\end{tabular}

Berdasarkan hasil yang telah diperoleh dari koefisien regresi di atas, maka dapat dibuat suatu persamaan regresi sebagai berikut:

$$
Y=13,570+0,528 X_{1}+0,179 X_{2}
$$

Dari persamaan tersebut dapat diambil kesimpulan bahwa:

a. Konstanta sebesar 13,570 menyatakan bahwa jika kompensasi (x1) dan disiplin kerja (x2) bernilai 0 (nol), maka kinerja karyawan (Y) nilainya sebesar 13,570

b. Koefisien regresi kompensasi (x1) sebesar 0,528 menyatakan bahwa setiap penambahan $1 \%$ variabel kompensasi, maka akan menaikan kinerja karyawan sebesar 0,528 dengan asumsi variabel lain bernilai tetap.

c. Koefisien regresi disiplin kerja (x2) sebesar 0,179 menyatakan bahwa setiap penambahan (karena bernilai positif) $1 \%$ disiplin kerja maka akan meningkatkan kepuasan kerja sebesar 0,179 dengan asumsi variabel lain bernilai tetap.

\section{Hasil Koefisien Determinasi}

Makna koefisien determinasi dalam analisis regresi linier. Dimana koefisien determinasi ( $\mathrm{R}$ Square) atau sering disimbolkan dengan $\mathrm{R} 2$ dimaknai sebagai sumbangan pengaruh variabel bebas $(\mathrm{X})$ terhadap variabel terikat $(\mathrm{Y})$.

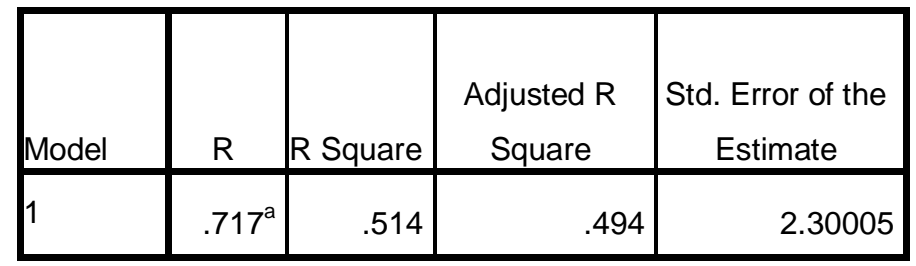

a. Predictors: (Constant), X2, X1 
Berdasarkan tabel di atas diketahui nilai R-Square (r2) sebesar 0,717 atau 51,4\%. Jadi dapat disimpulkan bahwa kompensasi dan disiplin kerja mempengaruhi kinerja karyawan sebesar $92,5 \%$, sedangkan sisanya dipengaruhi oleh faktor lain

\section{KESIMPULAN DAN SARAN}

\section{A. Kesimpulan}

Berdasarkan data yang didapatkan setelah diolah kembali, maka hasil penelitian tentang hubungan kompensasi dan disiplin kerja terhadap kinerja karyawan pada PT Pos Indonesia, dapat disimpulkan sebagai berikut:

1. Berdasarkan hasil dari pengujian hipotesis variabel x1 (kompensasi) terhadap variabel y (disiplin kerja) secara parsial diperoleh nilai thitung sebesar 7,045 dengan nilai signifikasi 0,000 dan ttabel 1,67. Karena thitung $>\operatorname{ttabel}(7,045>1,67)$ dan signifikansi $<0,05(0,000<0,05)$ maka dapat disimpulkan bahwa kompensasi secara parsial berpengaruh positif dan signifikan terhadap kinerja karyawan pada PT Pos Indonesia DC Ciputat.

2. Berdasarkan hasil dari pengujian hipotesis variabel x2 (disiplin kerja) terhadap variabel y (kinerja karyawan) secara parsial diperoleh nilai thitung sebesar 6,352 dengan nilai signifikasi 0,000 dan ttabel 1,67. Karena thitung > ttabel $(6,352>1,67)$ dan signifikansi $<0,05(0,000<0,05)$ maka dapat disimpulkan bahwa disiplin kerja secara parsial berpengaruh positif dan signifikan terhadap kinerja karyawan pada PT Pos Indonesia DC Ciputat.

3. Berdasarkan hasil dari pengujian hipotesis pengaruh $\mathrm{x} 1$ (kompensasi) dan $\mathrm{x} 2$ (disiplin kerja) diketahui nilai fhitung sebesar 24,883 dan nilai signifikansi sebesar 0,000 . Karena fhitung $>$ ftabel $(24,883>2,80)$ dan nilai signifikan $<0,05(0,000<0,05)$ maka dapat disimpulkan bahwa variabel kompensasi dan disiplin kerja berpengaruh positif dan siginifikan terhadap kinerja karyawan pada PT Pos Indonesia DC Ciputat.

\section{B. Saran}

Berdasarkan hasil penelitian, pembahasan dan kesimpulan diatas, penulis dapat memberikan saran yang berhubungan dengan kompensasi, disiplin kerja, dan kinerja karyawan, antara lain sebagai berikut:

1. Dari hasil penelitian kuesioner diperoleh rata-rata skor terkecil ada pada pernyataan nomor 3 yaitu "Upah yang diberikan tidak sesuai yang dijanjikan perusahaan", dengan rata-rata skor 3,86. Disarankan kepada pihak manajemen agar lebih teliti dan pemberiannya lebih konsisten dengan aturan yang dibuat dengan jelas sehingga setiap karyawan mendapatkan hak yang seharusnya didapat.

2. Dari hasil penelitian kuesioner diperoleh rata-rata skor terkecil ada pada pernyataan nomor 4 yaitu "Apabila karyawan mematuhi aturan perusahaan akan mendapatkan penghargaan", dengan rata-rata skor 3,56. Dalam hal ini disarankan perusahaan mengadakan reward/penghargaan disetiap bulan agar semua karyawan lebih mematuhi aturan perusahaan yang telah ditetapkan agar lebih disiplin dalam pekerjaan sehingga meningkatkan kinerja dan tidak adanya pekerjaan yang tertunda.

3. Dari hasil penelitian kuesioner diperoleh rata-rata skor terkecil ada pada pernyataan nomor 3 yaitu "Kemampuan yang saya miliki sesuai dengan pekerjaan yang diberikan", dengan rata-rata skor 4,1. Dalam hal ini disarankan harus mempunyai skill / kemampuan yang lebih jika diberikan pekerjaan yang lebih berat dan harus bisa bertanggung jawab atas pekerjaan yang diberikan agar tidak terjadi kesalahan.

4. Bagi peneliti selanjutnya diharapkan agar melakukan penelitian dengan jumlah populasi serta sampel yang lebih banyak lagi, sehingga data yang didapat bisa dikembangkan lebih baik. Dengan demikian hasil penelitian yang dibuat oleh peneliti 
selanjutnya dapat menggambarkan kecenderungan dari setiap variabel yang dibuat lebih akurat

\section{DAFTAR PUSTAKA}

B. Weather, W. d. (2014). Human Resource and Personnel Management. Surabaya: CV. R.A. Rozarie.

Ghozali, I. (2013). Aplikasi Analisis Multivariate Dengan Program SPSS. Semarang: Badan Penerbit Universitas Dipenogoro.

Ghozali, I. (2016). Aplikasi Analisis Multivariate Dengan Program SPSS. Semarang: Badan Penerbit Universitas Dipenogoro.

Hasibuan, M. (2017). Manajemen Sumber Daya Manusia. Jakarta: Bumi Aksara.

Husain, B. (2018). Pengaruh Disiplin Terhadap Kinerja karyawan pada pt bank danamon tbk cabang bintaro. Jurnal Disrubsi Bisnis, 1.

Istijanto. (2012). Riset Sumber Daya Manusia. Yogyakarta: PT Gramed Pustaka Utama.

Kadarisman. (2012). Manajemen Kompensasi. Jakarta: Rajawali Pers.

Mangkunegara, A. P. (2011). Manajemen Sumber Daya Manusia Perusahaan. Bandung: Rosdakarya.

Mangkunegara, A. P. (2013). Perancang Dan Pengembang Sumber Daya Manusia. Jakarta: Bumi Aksara.

Mangkunegara, A. P. (2017). Manajemen Sumber Daya Manusia Perusahaan. Bandung: Remaja Rosdakarya.

Moeheriono. (2012). Pengukuran Kinerja Berbasis Kompetensi. Jakarta: Raja Grafindo Persada.

Pratama, A. (2019). PENGARUH KOMITMEN ORGANISASI DAN KOMPENSASI TERHADAP KEPUASAN KERJA SERTA DAMPAKNYA TERHADAP KINERJA KARYAWAN. Jurnal Semarak, 122-141.

Samsudin, S. (2014). Manajemen Sumber Daya Manusia. Bandung: Pustaka Setia. Serdamayanti. (2011). Manajemen SDM Dan Produktifitas Kerja. Bandung: Refika Aditama. Siswandoko. (2011). Manajemen Sumber Daya Manusia. Jakarta: Nusantara Consulting. Sugiyono. (2016). Metode Penelitian Pendidikan (Pendekatan Kuantitatif, Kualitatif, dan $R \& D)$. Bandung: Alfabeta.

Sutrisno, E. (2011). Budaya Organisasi. Jakarta: Kencana Prenada Media Group.

Sutrisno, E. (2014). Manajemen Sumber Daya Manusia. Jakarta: Prenada Media Group. 